\title{
Exploring the Competitive Advantage of Local Creative Industry in Bali, Indonesia
}

\author{
I. Ketut Darma, Economic and Business Faculty, Warmadewa University, Denpasar-Bali, Indonesia. \\ Ni Luh Anik Puspa Ningsih, Economic and Business Faculty, Warmadewa University, Denpasar-Bali, Indonesia. \\ Ni Putu Pertamawati, Economic and Business Faculty, Warmadewa University, Denpasar-Bali, Indonesia.
}

\begin{abstract}
Bali as one of the tourism destination in Indonesia is strongly supported by the creative industry. This industry has produces products and services as a tourism and economic support in Bali. The creative industry development policy is carried out by the Bali provincial government, including in Buleleng regency. The potential of Buleleng Regency is a creative culture based on local culture. Tourism development, craft development, arts, and agricultural culture have been carried out in Buleleng Regency, but other potentially creative industry sectors are not mapped optimally. The aim of this study is to create a potential mapping of creative industries in Buleleng Regency and to optimizing its development strategy. This study use Importance Performance Analysis (IPA). This study showed the creative industry in Buleleng regency is in the level of empowered and independent qualifications. The empowerment level has the percentage of establishment 20\% - 50\%. This level consisting of Applications and game developers; Photography; Product design; Mode; Film, video, animation; Culinary; Music; Publishing; Advertising; Television and Radio. The independent level, with a percentage of establishment $51 \%$ - 80\% consist of 5 creative industry sectors, which is Architecture; Design; Visual communication; Craft; Performing arts and visual arts.
\end{abstract}

Keywords--- Creative Industry, Competitive Advantage, Importance Performance Analysis (IPA), Cartesian Chart.

\section{Introduction}

The development of the creative economy in the era of globalization is very necessary. The creative economy contributes substantially to the Indonesian economy. The creative economy gives contribution amounting to $7.44 \%$ based on Gross Domestic Product (GDP) (bekraf.go.id, 2018). This cannot be separated from the elements of the creative economy, namely the creative industry.

The creative Industry output from the utilization of individual creativity, expertise and talent to create added value, employment and increase the quality of life. This industry create a jobs and absorp a labor increasing $13 \%$ from the year before of the total national workforce (BPS, 2017)

In contrast, the creative industry still faces various obstacles, including 1) the linkage of professional and competitive creative human resources, 2) the availability of diverse, quality and competitive raw materials, 3) the development of industries that are competitive, growing and diverse, 4) the availability of financing appropriate, easy to access and competitive, 5) Expansion of markets for work, businesses and creative people, 6) availability of appropriate and competitive infrastructure and technology, and 7) institutional and business climate conducive to the development of a creative economy (Kemenparekraf, 2014 ; Hidayat and Nurdiana, 2016)

Bali as one of the tourist destinations located in Indonesia is also supported by the existence of creative industries. The development of the creative industry has become one of the focuses of the regional government of Bali Province.

This industry is able to reduce unemployment in Bali through an increase in the number of business units engaged in the creative economy by 5.21\%. Tourist visits, both international and domestic, have an impact on increasing economic activity in Bali. This triggered the strengthening of the secondary and tertiary sector groups and boosted market demand in the creative industry (Disperindag Provinsi Bali, 2017)

As one of the districts in Bali, Buleleng Regency has the potential in developing creative industries, especially based on local culture.

Creative industries based on local culture, namely industry by relying on the creativity of the community by utilizing the potential of the local Balinese culture available to be utilized as capital in gaining profits. (Dinas Statistik Kabupaten Buleleng, 2017)

Regional economic development policies related to the industry that are currently underway in Buleleng Regency are the development of cultural tourism, the development of crafts, arts, and agricultural culture. Other 
potential creative industry sectors in Buleleng have not been mapped optimally, have not yet synergized between the creative industry sector and between creative industry entrepreneurs and supporting infrastructure facilities (bulelengkab.go.id, 2018). This is one of the obstacles to the development of the creative economy so that studies need to be carried out regarding the mapping of the positions and competencies of the creative industry sectors in Buleleng Regency with the aim of optimizing the direction of development.

\section{Literature Review}

\section{Competitive Advantage}

The urgency of developing a creative economy is to create jobs through creative industry centers. Increase added value to products to create competitive advantage through the development of potential cultural resources to create value (Sasongko et al, 2018). Competitive advantage is the ability of a business entity to create products that are not able to be copied exactly by competitors. Every creative industry is required to have a competitive advantage over the products produced in order to be able to sustain a business on an ongoing basis.(Porter, $1998: 23$ )

\section{Creative Industry}

The creative industry is an element of the outputs of creative economy (products/services) from the utilization of creativity, expertise and individual talents to create added value, employment, and improve quality of life. The production of creative industries is in the form of creative works that can be consumed directly by households, companies and other economic entities that not only produce works that fulfill functions but also aesthetic values that can increase the happiness of consumers who consume them (kemenparekraf, 2014 ; Hidayat dan Nurdiana, 2016).

There are 16 sub-sectors of the creative industry in Indonesia, consist of 1) Game Application and Development; 2) Architecture; 3) Product Design; 4) Fashion; 5) Interior Design; 6) Visual Communication Design; 7) Performing Arts; 8) Film, Animation and Video; 9) Photography; 10) Craft; 11) Culinary; 12) Music; 13) Issuance; 14) Advertising; 15) Fine Art; 16) Television and Radio

\section{Geographical Location of Buleleng Regency}

Buleleng Regency consists of nine sub-districts namely Gerokgak, Seririt, Busungbiu, Banjar, Sukasada, Buleleng, Sawan, Kubutambahan and Tejakula. Buleleng Regency also consists of 129 Villages, with 1,365.88 Km2 areas (24.25\% of the Bali total area). Buleleng Regency located in the northern part of the island of Bali (Kabupaten Buleleng dalam Angka, 2018)

\section{Potential of Buleleng Regency}

Optimal development of creative economics is strongly supported by the resources possessed in an area. Optimal development of regional potential elements including activities, land, population demographics, local culture. The potential of the creative industries also as an influencer of the development of socio-economic industries (Sienkiewicz, 2014)

\section{1) Regional Topograhy}

Based on the topography, Buleleng Regency can be catagorize in four type ; ramps less than 45 degrees (51\%), steep (24\%), sloping (16\%) and flat area (9\%) (bulelengkab.go.id). Buleleng Regency has a potential land to support the creative economy.

\section{2) Population and Employment}

Based on the condition of the population, Buleleng Regency has a fairly large population of 653,600 people who are dominated by female sex. The large population must be balanced with the availability of employment for the working age population who has not worked. Because basically labor is another form of capital to icrease the economy. In 2016 the labor intensive program budget of the government was 184.7 million. The budget is able to absorb a workforce of 344 people in Buleleng Regency.

\section{3) Socio-Cultural}

Buleleng Regency has a unique philosophy of local wisdom which is contained in the dualistic concept (rwa bhineda). This concept is very influential on the pattern of local community settlements both village patterns and housing patterns, so that it manifests a certain pattern in terms of the shape and structure of villages or villages illustrated as follows, 

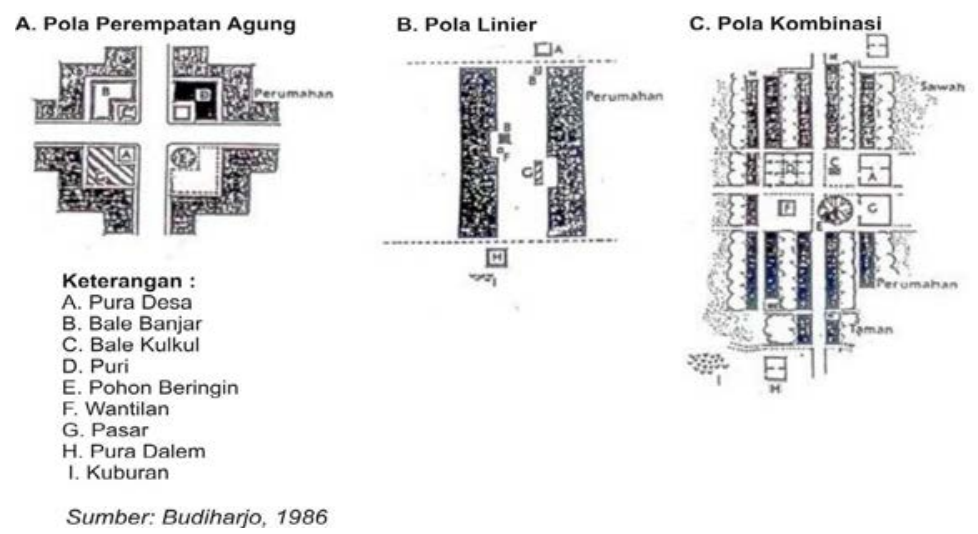

Figure 1: Shape Dan Structure of Village in Buleleng Regency

Culture is one of the factors that influence the development of a business based on uniqueness and creativity (Irwansyah and Tripalupi, 2019). The unique concept of social culture in Buleleng is one of the supporting aspects of the driving force of Buleleng tourism which in turn also has an impact on the existence of creative industries in Buleleng as a producer center for tourism products.

\section{4) Buleleng Regency Industrial Sector}

The industrial sector is a type of activity that gives a large role to the development of the creative economy in Buleleng Regency. The industrial sector consists of several types,

Figure 2: Buleleng Regency Industrial Sector

\begin{tabular}{|l|l|l|l|}
\hline \multirow{2}{*}{ Type of Industry } & \multicolumn{3}{|l|}{ Category (\%) } \\
\cline { 2 - 4 } & $\mathrm{L}$ & $\mathrm{M}$ & $\mathrm{S}$ \\
\hline Food and Beverage & 7,43 & 90,90 & 1,65 \\
\hline Textile, Clothing and Leather & 4,48 & 1,61 & 93,54 \\
\hline Bamboo, Wood, Rattan & 15,74 & 2,36 & 81,80 \\
\hline Media & 0,00 & 0,00 & 100,00 \\
\hline Physical building products & 0,00 & 1,38 & 97,61 \\
\hline Entertainment & 0,00 & 0,00 & 100,00 \\
\hline
\end{tabular}

Source: bulelengkab.go.id, 2018

\section{III.Research Method}

The study used (1) Surveys, conducted to map the potential of creative industries in Buleleng Regency; Bali (2) Importance Performance Analysis (IPA) conducted to analysis the degree of conformity between implementation performances with the level of importance, which will determine the priority scale in positioning from industry (Martila and James, 1977) in the creative industry in Buleleng Regency, Bali.

The science analysis was carried out in 2 (two) stages. The first stage are weighting, evaluating each item's perception-preference on the questionnaire by using a Likert scale consisting of five levels (1 - 5) assuming very well to not good. This assessment aims to measure the importance and reality of the creative industry sector in Buleleng Regency.

Stage II Cartesian diagram, presents the results of the assessment in the form of a diagram consisting of four quadrants, namely: (1) Quadrant I (Keep Up The Good Work), showing that the variables related to industry have a relatively high level of importance but the reality is not in accordance expectations of industry players, so that these variables must be immediately improved in performance. (2) Quadrant II (Possible Overkill), shows that the variables that have relatively high importance with a relatively high level of satisfaction. The variables that enter this quadrant are considered as supporting factors for the satisfaction of industry players so they must be maintained. (3) Quadrant III (Low Priority), shows that the variables related to the existence of the industrial sector have decreased, because both the level of importance and service quality are lower than the average value. (4) Quadrant IV (Concentrate Here), shows that the variables are related to the existence of an industrial sector with a relatively low level of importance and perceived by the user to be excessive with a relatively high level of satisfaction. 


\section{Results and Discussion}

The results of this study, there were 15 sub-sectors of industry found in Buleleng Regency. Interior design did not found in Buleleng Regency. Detail of the result are presented as follows,

\section{Analysis of the Potential of Creative Industries}

\section{Creation and Copyright on the Response to the Market Assessment}

Based on the results of calculations using the IPA analysis related to Creation and Copyright on the Response to the Market, can be described as follows:

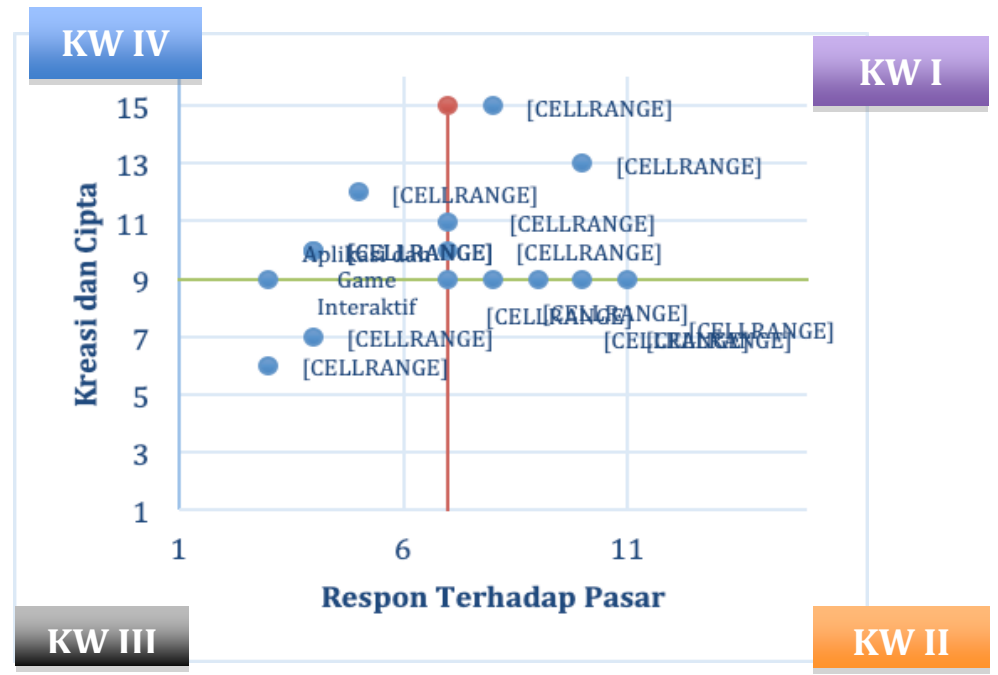

Figure 2: Creation and Copyright on the Response to the Market Assessment

Source : Analysis Result, 2019

The results of the cartesius diagram explain the magnitude of the link between creation and copyright and the response to the market. Quadrant I (gold / superior) includes, architecture; product design; fashion; visual communication design; craft; culinary; music; performing Arts; art. Whereas, for quadrant II (potential) there is no sub-sector that occupies the link between these two parameters. In quadrant III (lagging), includes photography; film, video, animation. Then, for quadrant IV (prospective), includes applications and game developers; publishing; advertising; television and radio.

\section{Creation and Copyright on the Active Development Environment Asessment}

Based on the creation and copyright on the active development environment assessment, the creative industry sector in Buleleng Regency can be presented in the following figure

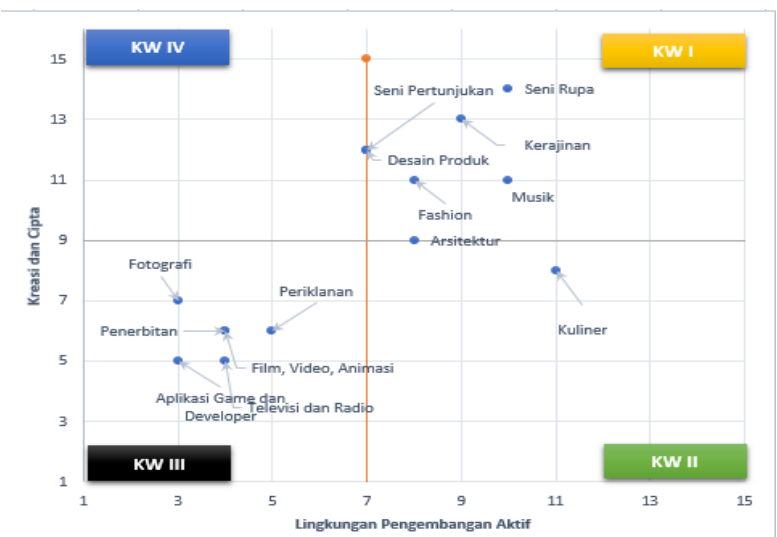

Figure 3: Creation and Copyright on the Active Development Environment Assessment

Source : Analysis Result, 2019 
Figure 3shown that each creative economy sub-sector is divided into four cartesius quadrants. In quadrant I consists of architecture; product design; fashion; visual communication design; craft; music; performing Arts; art. Whereas, in quadrant II consists of culinary. Quadrant III consists of game applications and developers; photography; film, video, animation; publishing; advertising; television and radio. For the relationship between creation and creativity with the active development environment does not produce sub-sectors that are classified into quadrant IV.

\section{Creation and Copywriting of the Passive Development Environment Asessment}

The relationship between creation and creativity with the passive development environment divides 15 subsectors into four kudran. In quadrant I, it consists of architecture; product design; visual communication design; craft; culinary; performing Arts; art. Whereas, on the second place consists of fashion and music. At Kudran III consists of applications and game developers; film, video, animation; advertising; television and radio. Then, on the IV screen consists of photography and publishing. Detail shown at the figure 4.

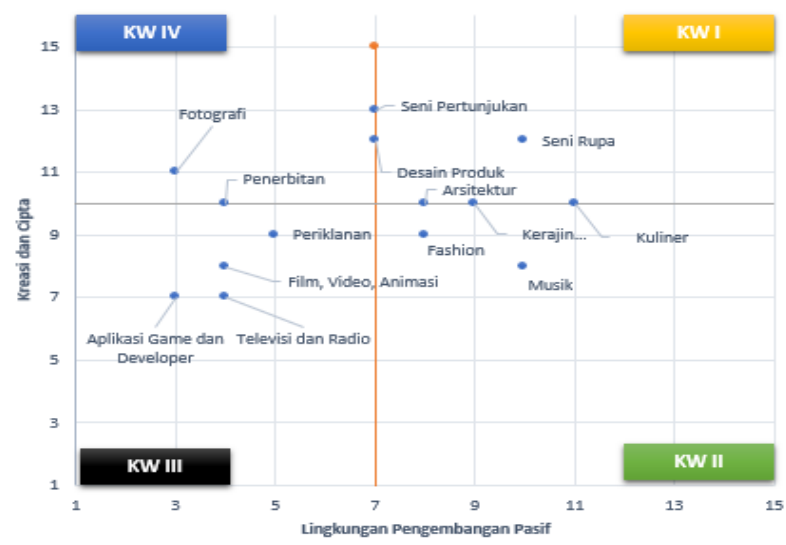

Figure 4: Creation and Copywriting of the Passive Development Environment Assessment

Source : Analysis Result, 2019

\section{Response to Markets with Active Development Environments Asessment}

Based on the results of the analysis of the relationship between Response to Markets and the Active Development Environment, it can be explained that 15 sub-sectors found in Buleleng Regency are divided into 4 cities. On snack I, includes architecture; product design; fashion; visual communication design; craft; music; performing Arts; art. In the quadrant there is no sub-sector that is classified because the value does not meet to enter quadrant II. Whereas, in quadrant III, includes photography; film, video, animation. Then, in quadrant IV, it includes applications and game developers; culinary; publishing; advertising; television and radio. Detail as shown as figure 5 .

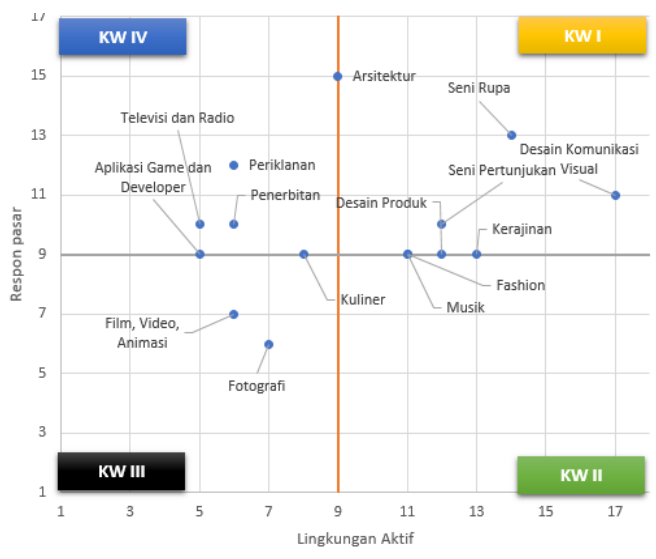

Figure 5: Response to Markets with Active Development Environments Asessment

Source : Analysis Result, 2019 


\section{Response to Markets with a Passive Development Environment Asessment}

Based on the results of the analysis, it can be seen that 15 existing sub-sectors are classified into 4 quadrants. In quadrant I, covering architecture; product design; visual communication design; craft; culinary; publishing; performing Arts; and fine arts. Whereas, in quadrant II, it includes photography. Kudaran III, covering film, video, animation. Then, in quadrant IV, it includes applications and game developers; fashion; music; advertising; television and radio. The result was shown as figure 6.

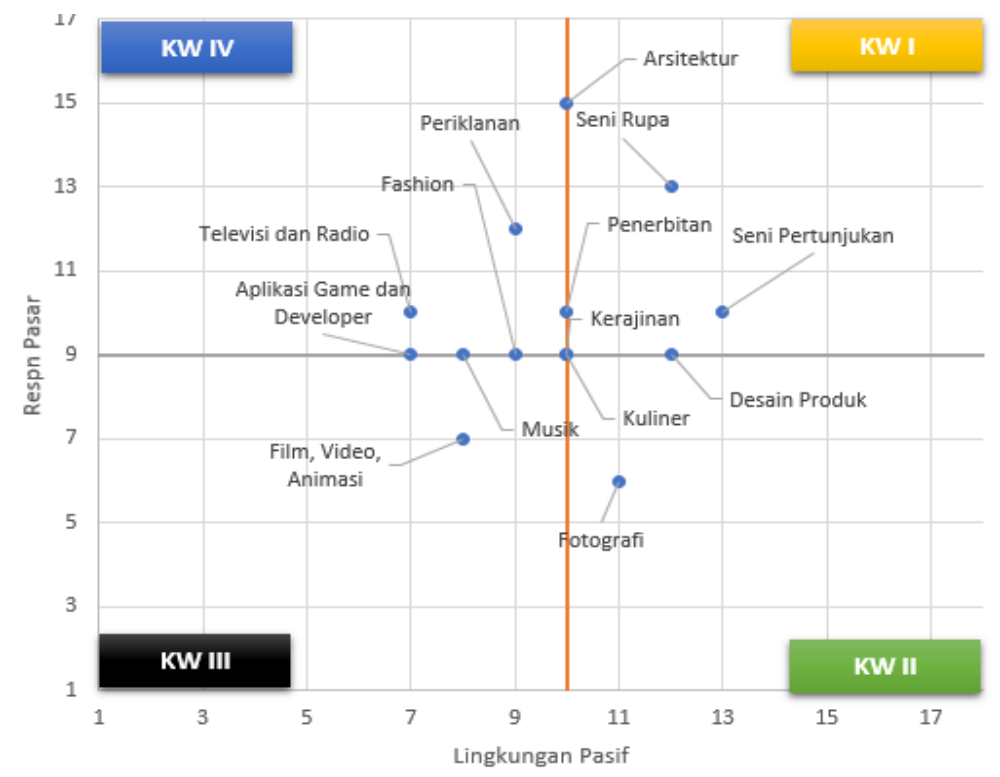

Figure 6: Response to Markets with a Passive Development Environment Assessment

Source: Analysis Result, 2019

\section{Active Development Environment and Passive Development Environment Assessment}

15 sub-sectors creative industries in Buleleng Regency are divided into 4 quadrants. In quadrant I, covering architecture; product design; visual communication design; craft; performing Arts; art. In quadrant II, covers fashion and music. Quadrant III, includes applications and game developers; film, video, animation; advertising; television and radio. Then in quadrant IV, including photography; culinary; and publishing. Complete presented in the following figure 7

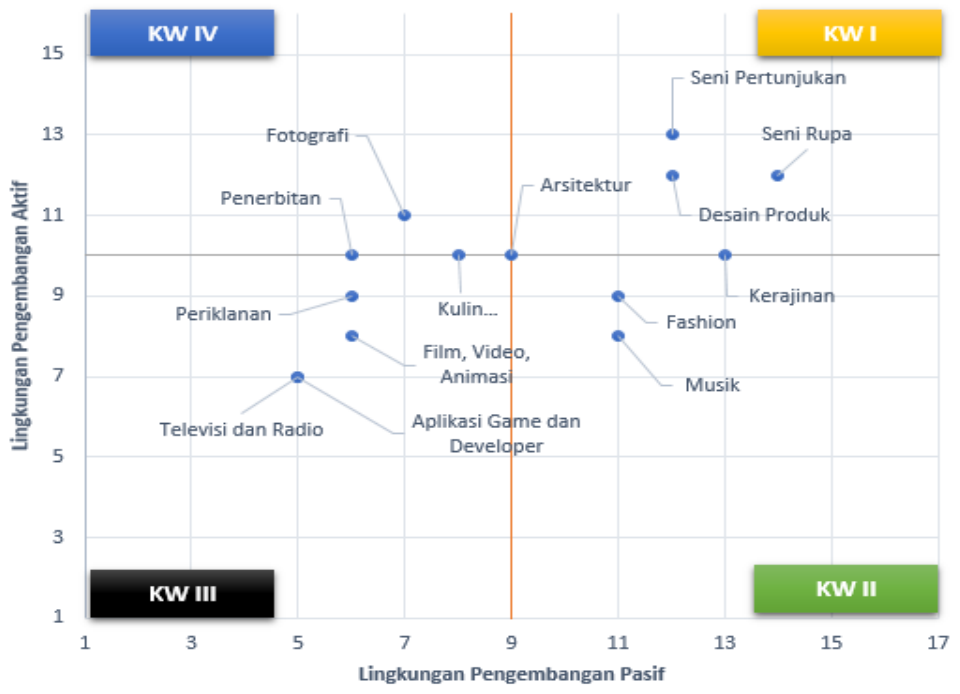

Figure 7: Active Development Environment and Passive Development Environment Assessment Source: Analysis Result, 2019 
Here are the summary of the the cartesian diagram (figure 4 to 9)

\begin{tabular}{|l|l|l|}
\hline Quadran & Description & Sub-Sector \\
\hline I & Superior & Architecture \\
& & Product Design \\
\cline { 3 - 3 } & & Visual Communication Design \\
\cline { 3 - 3 } & & Craft; \\
\cline { 3 - 3 } & & Performing Arts \\
\cline { 3 - 3 } & & Fine Art \\
\hline II & \multirow{2}{*}{ Potential } & Fashion \\
\cline { 3 - 3 } & & Music \\
\hline III & \multirow{2}{*}{ Lagging } & Film, Animation and Video \\
& & Photography \\
\cline { 3 - 3 } & & Issuance / Publishing \\
\hline IV & \multirow{3}{*}{ Prospective } & Game Application and Development \\
& & Advertising; \\
\cline { 3 - 3 } & & Television and Radio \\
\cline { 3 - 3 } & & Culinary \\
\hline
\end{tabular}

Figure 8: Cartesius Diagram Summary

Source: Analysis Result, 2019

\section{Establishment of a Creative Economy Analysis}

The results of the establishment analysis on each creative economy sub-sector can be seen as follows

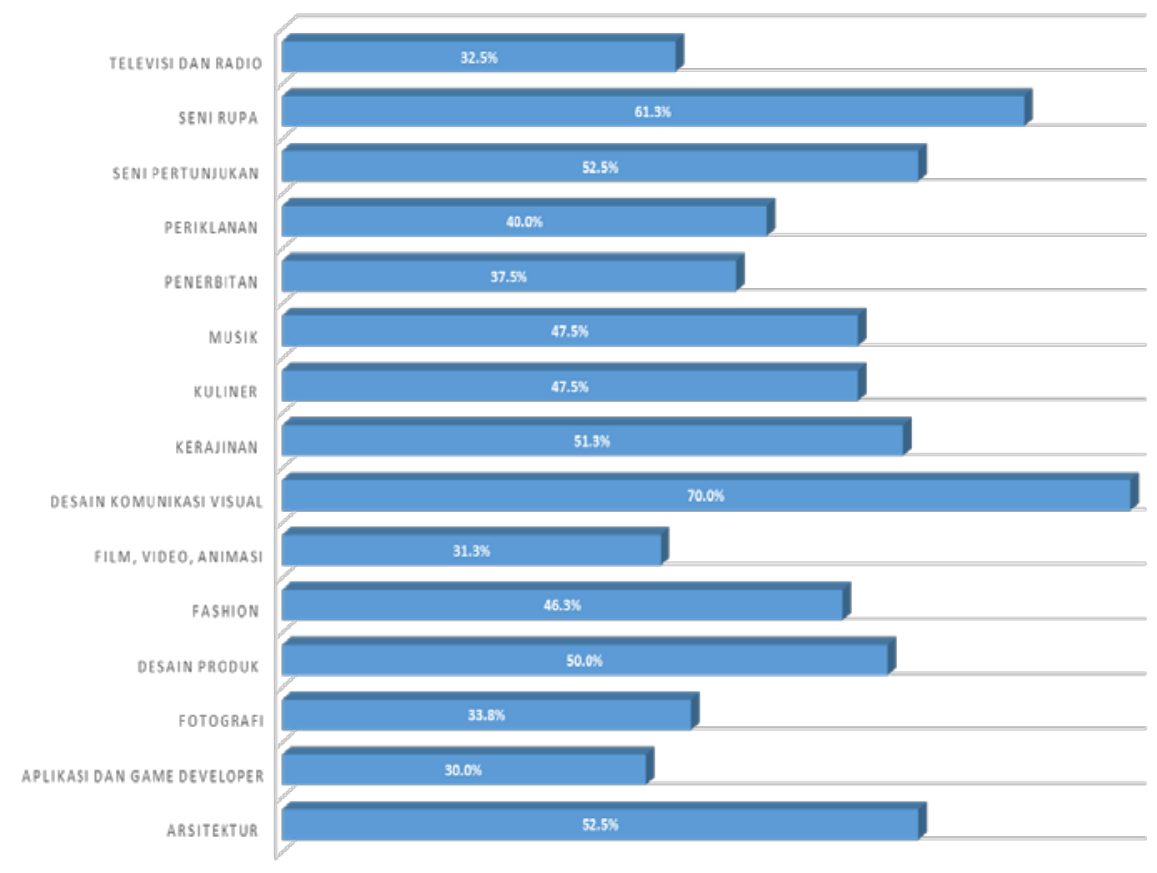

Source: Analysis Result, 2019

Figure 9: Establishment Percentage Value

The results of the establishment of sub-sector analysis in the table above, explain the sub-sectors to the parameters of establishment which are divided into pre-empowered, empowered, independent, and established.

Pre-empowered qualifications have a percentage between $0 \%$ - $20 \%$, empowered qualifications have a percentage of $20 \%-50 \%$, independent qualifications have a percentage between $50 \%-80 \%$, and established qualifications have a percentage between $80 \%$ - 100\%. Detail as shown as figure 10 
Figure 10: Sub Sector Qualifications

\begin{tabular}{|c|c|c|c|c|}
\hline Percentage & $\begin{array}{l}\text { Pre- } \\
\text { empowered }\end{array}$ & Empowered & Mandiri & Established \\
\hline \multicolumn{5}{|l|}{$0 \%-20 \%$} \\
\hline $20 \%-50 \%$ & & $\begin{array}{l}\text { - Application and game } \\
\text { developer } \\
\text { - Photography } \\
\text { - Product design } \\
\text { - Fashion } \\
\text { - Movies, videos, animations } \\
\text { - Culinary } \\
\text { - Music } \\
\text { - Publishing } \\
\text { - Advertising } \\
\text { - Television and Radio }\end{array}$ & & \\
\hline $51 \%-80 \%$ & & & $\begin{array}{ll}\text { - } & \text { Architecture } \\
- & \text { Visual communication } \\
\text { design } \\
\text { - } & \text { Crafts } \\
\text { - } & \text { Performing Arts } \\
- & \text { Fine Art }\end{array}$ & \\
\hline 81\%-100\% & & & & \\
\hline
\end{tabular}

Source: Analysis Result, 2019

\section{Conclusion and Recommendation}

Based on the grouping process of each creative economy sub-sector, then developed related to the criteria that can be developed, it can be concluded that the creative industry in Buleleng Regency depends on the level of empowered and independent qualifications. Helpless qualification level, with the percentage of establishment $20 \%$ $50 \%$ as many as 10 industry sub-sectors consisting of Applications and game developers; Photography; Product design; Mode; Film, video, animation; Culinary; Music; Publishing; Advertising; Television and Radio. Independent qualification level, with a percentage of establishment $51 \%$ - $80 \%$ of the total 5 creative industry sectors, consisting of Architecture; Design; Visual communication; Craft; Performing arts and visual arts.

Based on the result of this study we are suggesting, (1) For local governments The results of the study are expected to be one of the references to find concepts and directives that can be offered in preparation for the Buleleng Regency Creative Economy Development Plan. (2) For Further Researchers, Can Make a Study Based on Further Reviews related to Creative Industry Development and Analysis of Factors Affecting the Performance of Creative Industries in Buleleng Regency.

\section{References}

[1] Badan Pusat Statistik (BPS). 2017. Provinsi Bali Dalam Angka. Versi online, diakses 1 Januari 2018.

[2] Budiharjo, Eko. 1996. Arsitektur Sebagai Warisan Budaya. Semarang : Karya Unipress

[3] Dinas Perindustrian dan Perdagangan Provinsi Bali (Disperindag), 2017.

[4] Dinas Statistik Kabupaten Buleleng. 2017. Statistik Daerah Kabupaten Buleleng. Versi online, diakses 10 Pebruari 2018

[5] Hidayat, AS. dan Nurdiana, E. 2016. Strategi Pengembangan SDM Industri Kreatif Indonesia dalam Menghadapi Masyarakat Ekonomi ASEAN pada Tahun 2016. Prosiding Seminar Nasional Indonesian Conference on Management, Politics, Accounting and Communications, p.193-206

[6] Irwansyah, M. Rudi. and Tripalupi, Lulup Endah. 2019. Entrepreneurship Forming Through Entrepreneur Education. Advances in Economics, Business and Management Research, Vol. 69. p.142-144

[7] Kementrian Pariwisata dan Ekonomi Kreatif (kemenparekraf), 2014.

[8] Martila, John A. and James, John C. 1977. Importance Performance Analysis. Journal of Marketing. p.7779

[9] Official Website Badan Ekonomi Kreatif Indonesia (www.bekraf.go.id), 2018.

[10] Official Website Kabupaten Buleleng (www.bulelengkab.go.id), 2018. 
[11] Porter, Michael. E. 1998. Competitive Advantage : Creating and Sustaining Superior Porformance. Newyork: The Free Press

[12] Sasongko, Totok ; Rifa'i Muhamad ; Sayekti, Rr Nugraheni Suci. 2018. The Development of the Creative Industries to Create a Competitive Advantage : Study in Small Business Sector. Journal of Economic Development, Environment and People. Jakarta 2-3 Mei 2016, Vol.7, Issue.3

[13] Sienkiewicz, Marius Wiktor. 2014. Local Economic Development Policy in Poland : Determinants and Outcomes. Science and Development. Vol.32, p.405-427 